\title{
Neuronal L-Type Calcium Channels Open Quickly and Are Inhibited Slowly
}

\author{
Thomas D. Helton, ${ }^{*}$ Weifeng $\mathrm{Xu},{ }^{*}$ and Diane Lipscombe \\ Department of Neuroscience, Brown University, Providence, Rhode Island 02912
}

\begin{abstract}
Neuronal L-type calcium channels are essential for regulating activity-dependent gene expression, but they are thought to open too slowly to contribute to action potential-dependent calcium entry. A complication of studying native L-type channels is that they represent a minor fraction of the whole-cell calcium current in most neurons. Dihydropyridine antagonists are therefore widely used to establish the contribution of L-type channels to various neuronal processes and to study their underlying biophysical properties. The effectiveness of these antagonists on L-type channels, however, varies with stimulus and channel subtype. Here, we study recombinant neuronal L-type calcium channels, $\mathrm{Ca}_{\mathrm{V}} 1.2$ and $\mathrm{Ca}_{\mathrm{V}} 1.3$. We show that these channels open with fast kinetics and carry substantial calcium entry in response to individual action potential waveforms, contrary to most studies of native L-type currents. Neuronal $\mathrm{Ca}_{\mathrm{V}} 1.3 \mathrm{~L}$-type channels were as efficient as $\mathrm{Ca}_{\mathrm{v}} 2.2 \mathrm{~N}$-type channels at supporting calcium entry during action potential-like stimuli. We conclude that the apparent slow activation of native L-type currents and their lack of contribution to single action potentials reflect the state-dependent nature of the dihydropyridine antagonists used to study them, not the underlying properties of L-type channels.
\end{abstract}

Key words: action potential; low-threshold calcium channel; calcium channels; dihydropyridine; L-type; $\alpha 1 \mathrm{D} ; \alpha 1 \mathrm{C} ; \mathrm{Ca}_{\mathrm{V}} 1.2 ; \mathrm{Ca}_{\mathrm{V}} 1.3$

\section{Introduction}

Two major forms of L-type calcium channels, $\mathrm{Ca}_{\mathrm{V}} 1.2$ and $\mathrm{Ca}_{\mathrm{V}} 1.3$, are expressed throughout the nervous system and have different biophysical and subcellular distributions (Hell et al., 1993; Ludwig et al., 1997; Lipscombe et al., 2004). Dihydropyridine antagonist blockade demonstrates that L-type calcium channels are critical for activity-dependent gene expression and for regulating plasticity at certain synapses (Murphy et al., 1991; Magee and Johnston, 1997; Brosenitsch et al., 1998; Hardingham et al., 1998; Weisskopf et al., 1999; Mermelstein et al., 2000; Dolmetsch et al., 2001; Lei et al., 2003). In contrast, the general lack of effect of dihydropyridine antagonists on transmitter release implies that L-type calcium channels play a limited role in the control of presynaptic calcium entry at most synapses (Dunlap et al., 1995; Elliott et al., 1995).

L-type calcium channels preferentially localize to soma and dendrites of neurons (Hell et al., 1993; Simon et al., 2003), but their contribution to action potential-dependent calcium entry in these regions is unclear. Dihydropyridine antagonists are either completely or only weakly effective against action potentialdependent calcium entry in dendritic spines (Yasuda et al., 2003;

\footnotetext{
Received March 20, 2005; revised Sept. 21, 2005; accepted Sept. 23, 2005.

${ }^{*}$ T.D.H. and W.X. contributed equally to this work.

This work was supported by National Institutes of Health Grants NS29967 (D.L.) and MH19118 (T.D.H.). We thank Alison Amenta for assisting in constructing Cay 1.2 cDNA.

Correspondence should be addressed to Diane Lipscombe, Department of Neuroscience, Brown University, 190 Thayer Street, Providence, RI 02912. E-mail: Diane_Lipscombe@brown.edu.

T. D. Helton's present address: Department of Neurobiology, Duke University Medical Center, Durham, NC 27710. W. Xu's present address: Nancy Friend Pritzker Laboratory, Department of Psychiatry and Behavioral Sciences, Stanford University School of Medicine, Palo Alto, CA 94304-5485.

DOI:10.1523/JNEUROSCI.1089-05.2005

Copyright $\odot 2005$ Society for Neuroscience $\quad$ 0270-6474/05/2510247-05\$15.00/0
}

Hoogland and Saggau, 2004). Pairing action potentials with excitatory synaptic potentials and repetitive or prolonged stimulation, however, can apparently recruit L-type calcium channels, based on observations that dihydropyridine antagonists block calcium entry in dendrites and cell bodies when induced by these types of stimuli (Magee and Johnston, 1997; Brosenitsch et al., 1998; Deisseroth et al., 1998; Mermelstein et al., 2000). It has therefore been suggested that L-type channels normally open too slowly to respond to single action potentials but that they can be recruited under conditions that promote prolonged membrane depolarization (Bonci et al., 1998; Mermelstein et al., 2000; Brosenitsch and Katz, 2001; Yasuda et al., 2003).

Dihydropyridine antagonists are used widely to establish the contribution of L-type channels to various neuronal processes, but the effectiveness of these blockers depends on membrane potential, channel state, and channel subtype (Bean, 1984; Hess et al., 1984; Holz et al., 1988; Scroggs and Fox, 1992; Xu and Lipscombe, 2001; Koschak et al., 2003). Dihydropyridine antagonists are less effective on L-type calcium currents activated by brief stimuli and from hyperpolarized voltages, conditions that limit channel entry into the inactivated state (Holz et al., 1988; Scroggs and Fox, 1992). Furthermore, concentrations of dihydropyridine antagonists that completely inhibit $\mathrm{Ca}_{\mathrm{V}} 1.2$ channels are only partially effective on $\mathrm{Ca}_{\mathrm{V}} 1.3 \mathrm{~L}$-type calcium channels (Koschak et al., 2001; Xu and Lipscombe, 2001; Lipscombe et al., 2004).

Here, we study recombinant neuronal $\mathrm{Ca}_{\mathrm{V}} 1.2$ and $\mathrm{Ca}_{\mathrm{V}} 1.3$ channels and show that these L-type calcium channels open over a range of voltages and activate rapidly in response to a variety of stimuli including individual action potential waveforms. Our data suggest that certain properties attributed to neuronal L-type channels, such as slow activation, are more reflective of the state- 
dependent action of the dihydropyridine antagonists used to study them and not the kinetics of native L-type currents.

\section{Materials and Methods}

Electrophysiology. $\mathrm{Ca}_{\mathrm{V}} 1.2$ and $\mathrm{Ca}_{\mathrm{V}} 1.3$ clones were expressed transiently in tsA201 cells. We cloned neuronal $\mathrm{Ca}_{\mathrm{V}} 1.2$ from mouse brain (GenBank accession number AY728090). The other clones were rat neuronal $\mathrm{Ca}_{\mathrm{V}} 1.3$ (GenBank accession number AF370009), rat neuronal $\mathrm{Ca}_{\mathrm{V}} 2.2$ (GenBank accession number AF055477), rat neuronal $\mathrm{Ca}_{\mathrm{V}} 3.1$ (GenBank accession number AF027984), rat neuronal $\mathrm{Ca}_{\mathrm{V}} \beta_{3}$ (sequence same as GenBank accession number M88751), and $\mathrm{Ca}_{\mathrm{V}} \alpha_{2} \delta_{1}$ (GenBank accession number AF286488). We used equimolar ratios of $\mathrm{Ca}_{\mathrm{V}} \alpha_{1}, \mathrm{Ca}_{\mathrm{V}} \beta_{3}, \mathrm{Ca}_{\mathrm{V}} \alpha_{2} \delta_{1}$, and enhanced green fluorescent protein cDNAs to transfect cells using Lipofectamine 2000 (Invitrogen, San Diego, CA). Fluorescent cells were selected for recording as described previously (Thaler et al., 2004). Currents were measured $2 \mathrm{~d}$ after transfection by the whole-cell voltage-clamp method (Axopatch 200A), and data were analyzed using pClamp 8 software (Molecular Devices, Union City, CA). Currents were sampled at $10 \mathrm{kHz}$ and low-pass filtered at $2 \mathrm{kHz}$. Patch pipettes, fire polished to a resistance of 2.5-5 $\mathrm{M} \Omega$ and Sylgard (Dow Corning, Midland, MI) coated, contained the following (in $\mathrm{mm}$ ): $135 \mathrm{CsCl}, 4 \mathrm{MgATP}, 10$ HEPES, 1 EGTA, and 1 EDTA, pH 7.4 CsOH. Bath solution contained the following (in $\mathrm{mM}$ ): 135 choline- $\mathrm{Cl}, 1 \mathrm{MgCl}_{2}, 2 \mathrm{CaCl}_{2}$, and 10 HEPES, $\mathrm{pH} 7.4 \mathrm{CsOH}$. Series resistance was compensated $80-85 \%$ with an $8 \mu$ s lag time. Current-voltage relationships were fit to Boltzmann Goldmann-Hodgkin-Katz (GHK) functions.

Solutions. A $10 \mathrm{~mm}$ stock of nifedipine (gift from Bayer Pharmaceuticals, West Haven, CT) was prepared in polyethylene glycol 400 and diluted to $5 \mu \mathrm{M}$ in recording bath solution. After patching, cells were placed $\sim 200 \mu \mathrm{m}$ from the mouth of a small-diameter fiberglass perfusion tube (inner diameter, $250 \mu \mathrm{m}$; Polymicron Technologies, Phoenix, AZ). Nifedipine solution was applied under constant flow. External solutions were exchanged in $<1$ s by moving the cell between continuously flowing solutions from the perfusion tubes.

\section{Results}

\section{L-type channels activate at negative voltages}

We first compared current-voltage profiles of neuronal $\mathrm{Ca}_{\mathrm{V}} 1.2$ and $\mathrm{Ca}_{\mathrm{V}} 1.3$ L-type currents with neuronal $\mathrm{Ca}_{\mathrm{V}} 2.2$ and $\mathrm{Ca}_{\mathrm{V}} 3.1$ channels. $\mathrm{Ca}_{\mathrm{V}} 1.2$ and $\mathrm{Ca}_{\mathrm{V}} 1.3$ channels underlie L-type currents in the majority of neurons. $\mathrm{Ca}_{\mathrm{V}} 2.2 \mathrm{~N}$-type channels represent a classic fast-activating, high-voltage-activated, presynaptic calcium channel, whereas the $\mathrm{Ca}_{\mathrm{V}} 3.1 \mathrm{~T}$-type channel constitutes a low-voltage-activating, slowly deactivating calcium channel (Perez-Reyes et al., 1998). Currents were activated from a holding potential of $-100 \mathrm{mV}$ and recorded with $2 \mathrm{mM} \mathrm{Ca}^{2+}$ as the charge carrier (Fig. 1a). The combined activity of neuronal $\mathrm{Ca}_{\mathrm{V}} 1.2$ and $\mathrm{Ca}_{\mathrm{V}} 1.3$ channels suggests L-type calcium channels can activate over a wide range of voltages; activation thresholds are negative to $\mathrm{Ca}_{\mathrm{V}} 2.2 \mathrm{~N}$-type calcium channels (Avery and Johnston, 1996; Elmslie, 1997; Mermelstein et al., 2000) and positive to $\mathrm{Ca}_{\mathrm{V}}$ 3.1 T-type channels (Perez-Reyes et al., 1998).

\section{L-type channels open rapidly}

$\mathrm{Ca}_{\mathrm{V}}$ 1.3 L-type channels opened and closed with fast kinetics relative to $\mathrm{Ca}_{\mathrm{V}} 1.2$ channels. Examples of superimposed, normalized $C a_{V} 1.2, p<0.001$.
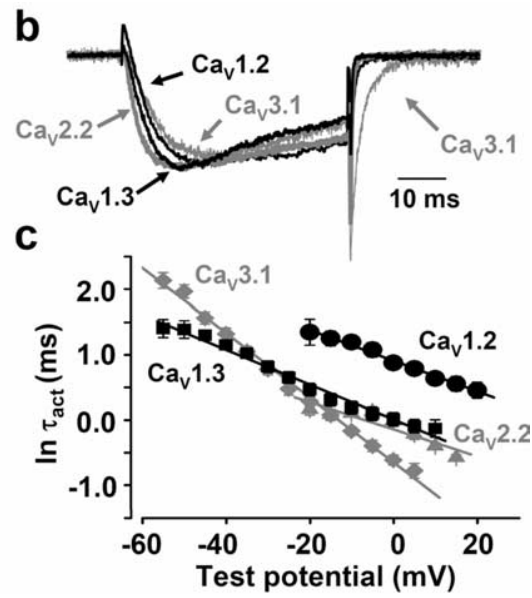

Test potential $(\mathrm{mV})$

Figure 1. Neuronal L-type channels activate over a wide voltage range and with fast kinetics. $\boldsymbol{a}$, Normalized, averaged current-voltage relationships for calcium currents recorded from tsA201 cells expressing $C a_{y} 1.3(\square), C a_{y} 1.2(\mathbf{O}), C a_{v} 2.2(\boldsymbol{\Delta})$, and data. Slopes and y intercepts are the following: $C a_{v} 1.3,-0.02 \pm 0.001 \mathrm{mV}^{-1}, 0.23 \pm 0.02(n=9) ;\left(a_{v} 1.2,-0.02 \pm 0.003\right.$ $\mathrm{mV}^{-1}, 0.89 \pm 0.09(n=11) ;\left(\mathrm{a}_{\mathrm{v}} 2.2,-0.02 \pm 0.001 \mathrm{mV}^{-1},-0.11 \pm 0.01(n=7) ;\right.$ and $\mathrm{Ca}_{\mathrm{v}} 3.1,-0.049 \pm 5 \times 10^{-4}$ $\mathrm{mV}^{-1},-0.63 \pm 0.07(n=6)$. Student's $t$ test on time constants at all test potentials: $C a_{\mathrm{v}} 1.3$ to $C a_{\mathrm{v}} 2.2, p>0.27 ; C a_{\mathrm{v}} 1.3$ to

representative currents for each channel demonstrate that activation rates of $\mathrm{Ca}_{\mathrm{V}} 1.3, \mathrm{Ca}_{\mathrm{V}} 2.2$, and $\mathrm{Ca}_{\mathrm{V}} 3.1$ currents are comparable and faster compared with $\mathrm{Ca}_{\mathrm{V}} 1.2$ (Fig. 1b,c). Activation time courses of $\mathrm{Ca}_{\mathrm{V}} 1.3$ currents were indistinguishable from $\mathrm{Ca}_{\mathrm{V}} 2.2$ over a range of test potentials, whereas $\mathrm{Ca}_{\mathrm{V}} 1.2$ currents opened with significantly slower kinetics (Fig. 1c). The voltage dependence of $\mathrm{Ca}_{\mathrm{V}} 3.1$ activation kinetics was steeper compared with $\mathrm{Ca}_{\mathrm{V}} 1.3$ and $\mathrm{Ca}_{\mathrm{V}} 2.2$ (Fig. 1c). Although slower compared with the other calcium channels, $\mathrm{Ca}_{\mathrm{V}} 1.2$ channels opened with a time course more rapid than is typically reported for native dihydropyridine-sensitive L-type currents (Mermelstein et al., 2000). $\mathrm{Ca}_{\mathrm{V}} 1.2, \mathrm{Ca}_{\mathrm{V}} 1.3$, and $\mathrm{Ca}_{\mathrm{V}} 2.2$ channels all closed rapidly and significantly faster than $\mathrm{Ca}_{\mathrm{V}} 3.1 \mathrm{~T}$-type channels. T-type channels displayed characteristic slow deactivation tails (Fig. $1 b$, supplemental Fig. 1, available at www.jneurosci.org as supplemental material).

\section{L-type channels are activated by action potential stimuli}

The rapid gating of $\mathrm{Ca}_{\mathrm{V}} 1.2$ and $\mathrm{Ca}_{\mathrm{V}} 1.3$ channels suggested that these channels should respond well to brief action potential-like stimuli. We confirmed this using action potential waveforms as command voltages to evoke currents from cells expressing $\mathrm{Ca}_{\mathrm{V}} 1.2, \mathrm{Ca}_{\mathrm{V}} 1.3$, and $\mathrm{Ca}_{\mathrm{V}} 2.2$ channels (holding potential, -80 $\mathrm{mV}$ ) (Fig. 2a) (McCobb and Beam, 1991). Action potential waveforms, derived from sympathetic neurons, induced $\mathrm{Ca}_{\mathrm{V}} 1.3$ currents with time courses indistinguishable from $\mathrm{Ca}_{\mathrm{V}} 2.2$, whereas $\mathrm{Ca}_{\mathrm{V}} 1.2$ channels opened with a slightly longer delay (Fig. $2 a$ ). The same result was obtained using an action potential waveform from a Purkinje neuron as the command voltage (supplemental Fig. 1 $a$, available at www.jneurosci.org as supplemental material). The average time delay between the peak of the command voltage waveform and the peak of the inward calcium current was close to $0.6 \mathrm{~ms}$ for both $\mathrm{Ca}_{\mathrm{V}} 1.3$ and $\mathrm{Ca}_{\mathrm{V}} 2.2$ channels, compared 
a

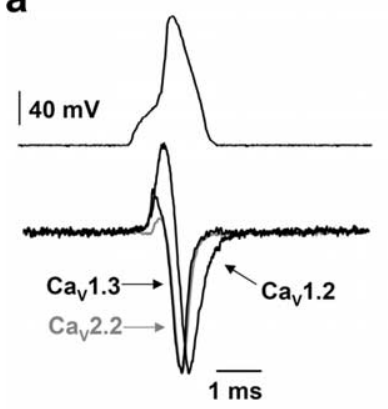

C

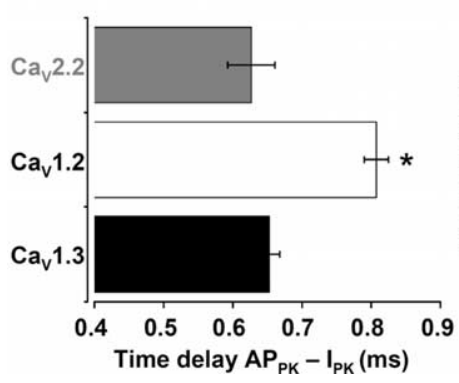

Figure 2. Ca 1.3 activates rapidly in response to action potential-like (AP) waveforms. Overlaid normalized ( $\boldsymbol{a}$ ) and non-normalized $(\boldsymbol{b})$ representative current traces for $\mathrm{Ca}_{\mathrm{v}} 1.2, \mathrm{Ca}_{\mathrm{v}} 1.3$, and $\mathrm{Ca}_{\mathrm{v}} 2.2$ channels in response to AP waveform are shown. The AP was recorded from a sympathetic neuron and was triggered by a brief current injection seen as a hump on the foot of the waveform. $c$, Average time delay between the peak of the action potential waveform $\left(\mathrm{AP}_{\mathrm{PK}}\right)$ and peak inward current $\left(I_{\mathrm{PK}}\right)$. Time delays were the following: $\mathrm{Ca}_{\mathrm{v}} 1.3,0.65 \pm 0.06 \mathrm{~ms}(n=$ 11); $\mathrm{Ca}_{\mathrm{v}} 1.2,0.81 \pm 0.05 \mathrm{~ms}(n=8) ;$ and $\mathrm{Ca}_{\mathrm{v}} 2.2,0.63 \pm 0.05 \mathrm{~ms}(n=8)$. $\mathrm{Ca}_{\mathrm{v}} 1.3$ and $\mathrm{Ca}_{\mathrm{v}} 2.2$ values were not significantly different; $C \mathrm{C}_{\mathrm{v}} 1.2$ and $\mathrm{Ca}_{\mathrm{v}} 1.3$ values were significantly different $\left({ }^{*} p<0.05\right)$. d, Averaged ratios of total charge moved during a single AP to peak inward current evoked from a $50 \mathrm{~ms}$ step depolarization. Average values were the following: $\mathrm{Ca}_{\mathrm{v}} 1.3,0.84 \pm$ $0.06(n=19) ;\left(a_{v} 1.2,0.61 \pm 0.05(n=8) ;\right.$ and $\mathrm{Ca}_{\mathrm{v}} 2.2,0.94 \pm 0.11(n=6)$. Average AP peak currents for $\mathrm{Ca}_{\mathrm{v}} 1.2, \mathrm{Ca}_{\mathrm{v}} 1.3$, and $\mathrm{Ca}_{\mathrm{v}} 2.2$ were $663 \pm 137 \mathrm{pA}(n=8), 1282 \pm 110 \mathrm{pA}(n=19)$, and $2898 \pm 1273 \mathrm{pA}(n=10)$, respectively. IV, Current-voltage. Error bars represent SE.

with close to $0.8 \mathrm{~ms}$ for $\mathrm{Ca}_{\mathrm{V}} 1.2$ (Fig. $2 a, c$ ). Action potentialevoked currents carried by $\mathrm{Ca}_{\mathrm{V}} 3.1$ channels peaked more slowly (0.85 ms), similar to $\mathrm{Ca}_{\mathrm{V}} 1.2$, but most notably, these channels deactivate slowly and permit calcium influx for several milliseconds after the membrane potential returns to $-80 \mathrm{mV}$ (McCobb and Beam, 1991) (supplemental Fig. 1b,c, available at www.jneurosci.org as supplemental material).

To compare the efficiency among $\mathrm{Ca}_{\mathrm{V}} 1.2, \mathrm{Ca}_{\mathrm{V}} 1.3$, and $\mathrm{Ca}_{\mathrm{V}} 2.2$ channels to support calcium entry, we calculated total charge moved in response to single action potential waveforms. Total charge was expressed relative to peak current amplitude evoked by step depolarizations for each cell. This normalized for differences in expression efficiencies among the clones (Fig. 2b). $\mathrm{Ca}_{\mathrm{V}} 1.3$ channels were at least as efficient as $\mathrm{Ca}_{\mathrm{V}} 2.2$ channels in supporting calcium entry during action potential-like stimulation, and $\mathrm{Ca}_{\mathrm{V}} 1.2$ channels were slightly less efficient (Fig. $2 d$ ). The use of peak current amplitudes to normalize for differences in expression efficiencies slightly underestimates $\mathrm{Ca}_{\mathrm{V}} 1.3$ values relative to $\mathrm{Ca}_{\mathrm{V}} 2.2$. This is because $\mathrm{Ca}_{\mathrm{V}} 1.3$ channels open at voltages negative to $\mathrm{Ca}_{\mathrm{V}} 2.2$, where the driving force on calcium is greater.

Our results clearly show that single action potentials can activate both $\mathrm{Ca}_{\mathrm{V}} 1.2$ and $\mathrm{Ca}_{\mathrm{V}} 1.3 \mathrm{~L}$-type calcium channels. Given this, why are single action potentials apparently so inefficient at recruiting L-type calcium channels (Bonci et al., 1998; Mermelstein et al., 2000; Brosenitsch and Katz, 2001; Yasuda et al., 2003)? We considered the a

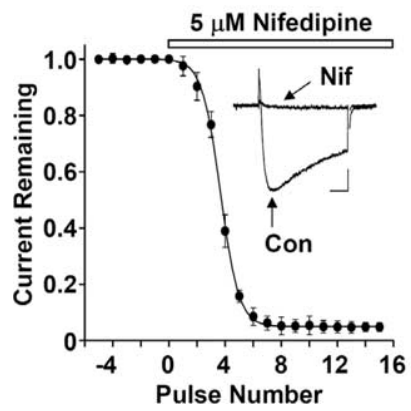

b

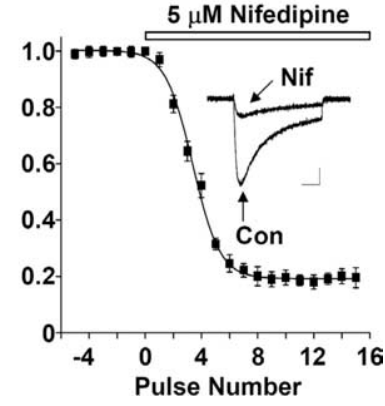

Figure 3. Nifedipine inhibits $C a_{v} 1.2$ and $C a_{v} 1.3$ channels activated by step depolarization. The time courses of inhibition of $C a_{v} 1.2(\boldsymbol{a} ; \boldsymbol{O})$ and $C a_{v} 1.3(\boldsymbol{b} ; \boldsymbol{\square})$ currents by $5 \mu \mathrm{m}$ nifedipine ( $n=7$ and $n=8$, respectively) are shown. Currents were evoked by $50 \mathrm{~ms}$ square pulse depolarizations to $0 \mathrm{mV}\left(\mathrm{Ca}_{\mathrm{V}} 1.2\right)$ and $-20 \mathrm{mV}\left(\mathrm{Ca}_{\mathrm{V}} 1.3\right)$ from a holding potential of $-80 \mathrm{mV}$. Depolarizations were applied once every $2 \mathrm{~s}$. The bars show duration of nifedipine application. Insets, Representative $\mathrm{Ca}_{\mathrm{V}} 1.2$ and $\mathrm{Ca}_{\mathrm{V}} 1.3$ currents before ( $\mathrm{Con}$ ) and after exposure to nifedipine (Nif; 16 s time point). Calibration: $0.2 \mathrm{nA}, 10 \mathrm{~ms}$ for $\mathrm{Ca}_{\mathrm{v}} 1.2(\boldsymbol{a})$ and $0.5 \mathrm{nA}, 10 \mathrm{~ms}$ for $\mathrm{Ca}_{\mathrm{v}} 1.3(\boldsymbol{b})$. Error bars represent $\mathrm{SE}$.

possibility that the use of dihydropyridines in studies of native neuronal L-type channels has greatly underestimated their importance. We asked how stimulus type influences the effectiveness of dihydropyridine antagonists on $\mathrm{Ca}_{\mathrm{V}} 1.2$ and $\mathrm{Ca}_{\mathrm{V}} 1.3$ channel currents.

\section{Nifedipine inhibits L-type currents}

The dihydropyridine antagonist nifedipine is used widely to study neuronal L-type channels. We first confirmed that $5 \mu \mathrm{M}$ nifedipine completely inhibited $\mathrm{Ca}_{\mathrm{V}} 1.2$ currents activated by step depolarizations from a holding potential of $-80 \mathrm{mV}$ (Fig. $3 a$ ). Cells were exposed to maximum drug concentration within $1 \mathrm{~s}$, and inhibition of $\mathrm{Ca}_{\mathrm{V}} 1.2$ currents was complete within $12 \mathrm{~s}$ (six pulses) (Fig. $3 a$ ). In contrast, $\mathrm{Ca}_{\mathrm{V}} 1.3$ channels were partially inhibited. Twenty percent of the $\mathrm{Ca}_{\mathrm{V}} 1.3$ current remained in the presence of $5 \mu \mathrm{M}$ nifedipine even after a $20 \mathrm{~s}$ drug exposure (Fig. $3 b$ ). These data show that $5 \mu \mathrm{M}$ nifedipine completely inhibits $\mathrm{Ca}_{\mathrm{V}} 1.2$ currents and, consistent with our previous studies in the Xenopus oocyte expression system (Lipscombe et al., 2004), nifedipine is less effective on neuronal $\mathrm{Ca}_{\mathrm{V}} 1.3$ currents.

\section{Slow inhibition of L-type currents opened by action potential waveforms}

We next assessed the actions of nifedipine on neuronal L-type currents activated by action potential waveforms. The difference in the effectiveness of nifedipine on currents activated by these brief stimuli was striking. Nifedipine $(5 \mu \mathrm{M})$ had no significant effect on $\mathrm{Ca}_{\mathrm{V}} 1.2$ and $\mathrm{Ca}_{\mathrm{V}} 1.3$ currents evoked by the first 30 action potentials of the stimulus train, applied from holding potentials of -80 and $-60 \mathrm{mV}$ (Fig. $4 a-d$ ). This same concentration of nifedipine strongly inhibited $\mathrm{Ca}_{\mathrm{V}} 1.2$ and $\mathrm{Ca}_{\mathrm{V}} 1.3$ currents activated by step depolarizations (Fig. $3 a, b$ ). Effects of nifedipine were only significant after 60 action potential stimuli (applied in consecutive trains of 30 action potentials from a holding potential of $-80 \mathrm{mV}$; data not shown). Even after 90 pulses (three 30 pulse trains), a significant fraction of $\mathrm{Ca}_{\mathrm{V}} 1.2$ and $\mathrm{Ca}_{\mathrm{V}} 1.3$ currents remained unblocked at a holding potential of $-80 \mathrm{mV}(14.0 \pm 4.8$ and $38.1 \pm 4.1 \%$, respectively) (Fig. $4 c, d$ ). When activated from the more depolarized holding potential of $-60 \mathrm{mV}, \mathrm{Ca}_{\mathrm{V}} 1.2$ currents were inhibited completely after 90 pulses (Fig. 4c). Membrane depolarization promotes dihydropyridine inhibition (Bean, 1984), but even at the more depolarized membrane potential of $-60 \mathrm{mV}$, significant 
a
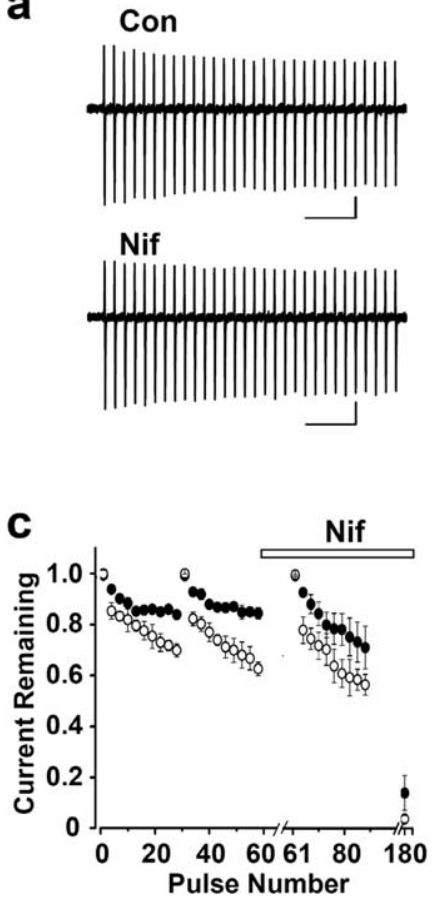

b
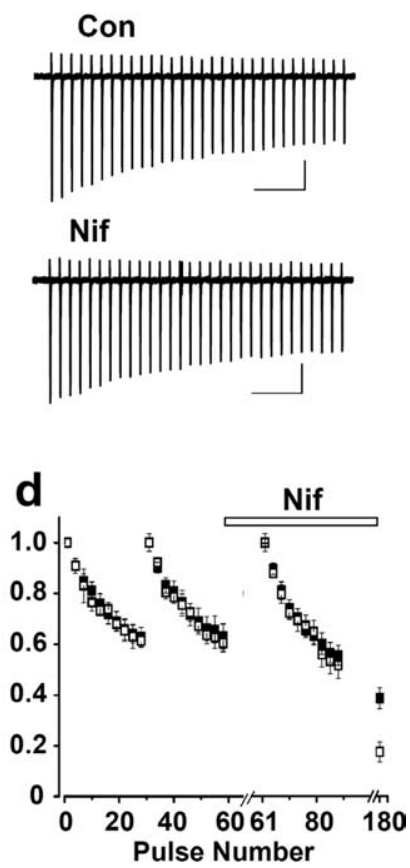

Figure 4. Nifedipine is weakly effective on $C a_{v} 1.2$ and $C a_{v} 1.3$ channels activated by action potential-like stimuli. Representative $C a_{v} 1.2(\boldsymbol{a})$ and $C a_{\mathrm{v}} 1.3(\boldsymbol{b})$ currents evoked by a train of action potential waveforms, applied at $100 \mathrm{~Hz}$ from holding potentials of $-80 \mathrm{mV}$, before (Con) and after a 10 s exposure to $5 \mu \mathrm{m}$ nifedipine (Nif), are shown. Calibration: $\boldsymbol{a}, 0.2 \mathrm{nA}, 50 \mathrm{~ms} ; \boldsymbol{b}, 0.5$ $\mathrm{nA}, 50 \mathrm{~ms}$. The action potential waveform used as command voltage was recorded from a sympathetic neuron and triggered by a brief current injection. Average peak current amplitudes for $C a_{v} 1.2(\boldsymbol{c} ; \mathbf{O}, \bigcirc)$ and $C a_{v} 1.3(\boldsymbol{d} ; \mathbf{\square}, \square)$ measured from currents induced by trains of 30 action potentials before and $10 \mathrm{~s}$ after exposure to $5 \mu \mathrm{m}$ nifedipine (Nif) are shown. Currents were evoked from holding potentials of $-80 \mathrm{mV}(\mathbf{O}, \mathbf{\square})$ and $-60 \mathrm{mV}(\bigcirc, \square)$. Current amplitudes at the end of a series of four stimulus trains in the presence of nifedipine are shown for each series (180th pulse). Currents recovered completely after removal of nifedipine within three stimulus trains. Recovery was slowed approximately threefold when the membrane potential was depolarized to $-60 \mathrm{mV}$. Error bars represent SE.

inhibition was only observed after a series of stimuli. Our data are generally consistent with state-dependent inhibition; preferential inhibition of the inactive state of the L-type calcium channel by dihydropyridines promotes channel inactivation (Berjukow and Hering, 2001). $\mathrm{Ca}_{\mathrm{V}} 1.3$ currents were, however, less sensitive to nifedipine, although $\mathrm{Ca}_{V} 1.3$ exhibited greater cumulative inactivation compared with $\mathrm{Ca}_{\mathrm{V}} 1.2$ in control recordings (Fig. $4 d$, first two trains). Cumulative inactivation of $\mathrm{Ca}_{\mathrm{V}} 1.3$ channels was calcium dependent (data not shown), and recovery from action potential-induced cumulative inactivation was rapid and complete in the absence of drug (Fig. $4 d$ ).

\section{Discussion}

We have studied the properties of the two most prevalent subtypes of neuronal L-type calcium channels in isolation from other currents. Our data show that both L-type channels open rapidly even in response to individual action potential waveforms, and $\mathrm{Ca}_{\mathrm{V}} 1.3$ channels are as efficient in this regard as $\mathrm{Ca}_{\mathrm{V}} 2.2 \mathrm{~N}$-type channels. Our findings are consistent with those by Liu et al. (2003), who found that a neuronal $\mathrm{Ca}_{\mathrm{V}} 1.2$ channel clone responded to action potential stimuli with kinetics similar to $\mathrm{Ca}_{\mathrm{V}}$ 2.1 P/Q-type.

If neuronal L-type channels open rapidly, why has it been so difficult to establish their contribution to action potentialdependent calcium entry in regions abundant in these channels
(Bonci et al., 1998; Mermelstein et al., 2000; Yasuda et al., 2003; Hoogland and Saggau, 2004)? Our study offers two possible explanations that both relate to the widespread use of dihydropyridine antagonists in studies of native neuronal L-type channels. First, in neurons that predominantly express $\mathrm{Ca}_{\mathrm{V}} 1.3$, a significant fraction of L-type current will be resistant to dihydropyridine antagonists (Xu and Lipscombe, 2001). Second, dihydropyridine inhibition of $\mathrm{Ca}_{\mathrm{V}} 1.2$ and $\mathrm{Ca}_{\mathrm{V}} 1.3 \mathrm{~L}$-type channels develops slowly. In the short term, these drugs will have little effect on L-type currents activated by action potential stimuli triggered from resting membrane potentials; significant inhibition will develop with continued stimulation or if the membrane potential is depolarized for a prolonged period. Thus, ineffectiveness of dihydropyridines does not necessarily rule out L-type calcium channel involvement in neuronal processes.

\section{$\mathrm{Ca}_{\mathrm{V}} 1.3$ currents are incompletely inhibited by dihydropyridine antagonists}

Many neurons, including those in the hippocampus, express $\mathrm{Ca}_{\mathrm{V}}$ 1.3 L-type calcium channels (Hell et al., 1993; Ludwig et al., 1997). These channels are incompletely inhibited by dihydropyridine antagonists (Figs. 3, 4) (Lipscombe et al., 2004). Because dihydropyridine antagonists inhibit L-type channels in a stateand time-dependent manner (Bean, 1984; Hess et al., 1984; Holz et al., 1988) (Fig. 4), the time course of dihydropyridine-sensitive currents in neurons expressing $\mathrm{Ca}_{\mathrm{V}} 1.3$ channels will reflect the time dependence of dihydropyridine block, not the kinetics of the underlying L-type current. The distortion in channel kinetics introduced by dihydropyridine antagonists is particularly evident when barium is used as the charge carrier [Lipscombe et al. (2004), their Fig. 3]). This may help explain why the dihydropyridine-sensitive component of L-type currents in hippocampal neurons appears to open with slow kinetics (Mermelstein et al., 2000), whereas neuronal L-type channels studied directly, without pharmacological subtraction, open rapidly (this study) (Liu et al., 2003; Michna et al., 2003).

\section{Nifedipine does not inhibit L-type channels opened by individual action potential stimuli}

Dihydropyridine antagonists do not inhibit $\mathrm{Ca}_{\mathrm{V}} 1.2$ or $\mathrm{Ca}_{\mathrm{V}} 1.3$ L-type channels opened by single action potential stimuli when triggered from a holding potential of $-60 \mathrm{mV}$ (Figs. 3, 4) (Holz et al., 1988; Liu et al., 2003). Thus, the lack of inhibition in neurons of action potential-dependent calcium entry by dihydropyridines (Bonci et al., 1998; Yasuda et al., 2003) does not necessarily exclude the involvement of L-type calcium channels. Indeed, if reevaluated in light of our data, several independent observations support L-type calcium channel involvement in action potentialdependent calcium entry in neurons (Scroggs and Fox, 1992; Magee and Johnston, 1997; Bonci et al., 1998; Mermelstein et al., 2000; Brosenitsch and Katz, 2001; Yasuda et al., 2003). In hippocampal spines, dihydropyridine antagonists are completely ineffective or weak inhibitors of spike-dependent calcium entry, but calcium transients are augmented greatly by dihydropyridine agonists and by $\beta$-adrenergic receptor activation (Yasuda et al., 2003; Hoogland and Saggau, 2004). Although dihydropyridine antagonists fail to inhibit action potential-dependent gene expression in primary sensory neurons, they inhibit gene expression induced by prolonged depolarization that would be expected to promote dihydropyridine inhibition (Brosenitsch and Katz, 2001). In sensory neurons, dihydropyridines inhibit a fraction of action potential-dependent calcium entry when tested from a more depolarized holding potential of $-60 \mathrm{mV}$ and with longer 
duration action potential waveforms (Scroggs and Fox, 1992). Finally, in the ventral mesencephalon, dihydropyridine antagonists inhibit neurotransmitter release during periods of highfrequency stimulation, but they are ineffective on transmitter release triggered early in the stimulus train (Bonci et al., 1998). The state-dependent nature of inhibition by dihydropyridine antagonists can readily explain all the aforementioned observations and raises the likely possibility that L-type calcium channels normally contribute to action potential-dependent calcium entry in these processes.

It is important to note that channel properties, including inactivation, are influenced by several factors including the type of associating $\mathrm{Ca}_{\mathrm{V}} \beta$ subunit and the pattern of alternative splicing. These factors may also influence dihydropyridine effectiveness. In our experiments, we coexpressed $\mathrm{Ca}_{\mathrm{V}} \alpha_{2} \delta_{1}$ and $\mathrm{Ca}_{\mathrm{V}} \beta_{3}$ subunits with $\mathrm{Ca}_{\mathrm{V}} 1.2$ and $\mathrm{Ca}_{\mathrm{V}} 1.3$, but the specific isoform and subunit composition of each complex may vary with cell type and subcellular location (Birnbaumer et al., 1998; Lipscombe et al., 2002; Liu et al., 2003).

\section{Conclusions}

We suggest that the importance of L-type calcium channels to neuronal processes that are triggered by brief membrane depolarizations has been underestimated. L-type channels derived from neurons have intrinsic properties that suggest they can contribute to calcium-mediated processes triggered by a wide range of stimuli including gene expression, transmitter release, and rhythmic firing (Holz et al., 1988; Bonci et al., 1998; Lipscombe et al., 2004). Dihydropyridine antagonists are highly effective tools for establishing the involvement of L-type channels in processes triggered by prolonged periods of membrane depolarization, but of limited use for studying processes predominantly triggered by brief physiological stimuli, including action potentials, from rest.

\section{References}

Avery RB, Johnston D (1996) Multiple channel types contribute to the lowvoltage-activated calcium current in hippocampal CA3 pyramidal neurons. J Neurosci 16:5567-5582.

Bean BP (1984) Nitrendipine block of cardiac calcium channels: high-affinity binding to the inactivated state. Proc Natl Acad Sci USA 81:6388-6392.

Berjukow S, Hering S (2001) Voltage-dependent acceleration of Ca(v)1.2 channel current decay by (+)- and (-)-isradipine. Br J Pharmacol 133:959-966.

Birnbaumer L, Qin N, Olcese R, Tareilus E, Platano D, Costantin J, Stefani E (1998) Structures and functions of calcium channel beta subunits. J Bioenerg Biomembr 30:357-375.

Bonci A, Grillner P, Mercuri NB, Bernardi G (1998) L-type calcium channels mediate a slow excitatory synaptic transmission in rat midbrain dopaminergic neurons. J Neurosci 18:6693-6703.

Brosenitsch TA, Katz DM (2001) Physiological patterns of electrical stimulation can induce neuronal gene expression by activating $\mathrm{N}$-type calcium channels. J Neurosci 21:2571-2579.

Brosenitsch TA, Salgado-Commissariat D, Kunze DL, Katz DM (1998) A role for L-type calcium channels in developmental regulation of transmitter phenotype in primary sensory neurons. J Neurosci 18:1047-1055.

Deisseroth K, Heist EK, Tsien RW (1998) Translocation of calmodulin to the nucleus supports CREB phosphorylation in hippocampal neurons. Nature 392:198-202.

Dolmetsch RE, Pajvani U, Fife K, Spotts JM, Greenberg ME (2001) Signaling to the nucleus by an L-type calcium channel-calmodulin complex through the MAP kinase pathway. Science 294:333-339.

Dunlap K, Luebke JI, Turner TJ (1995) Exocytotic Ca2 + channels in mammalian central neurons. Trends Neurosci 18:89-98.

Elliott EM, Malouf AT, Catterall WA (1995) Role of calcium channel subtypes in calcium transients in hippocampal CA3 neurons. J Neurosci 15:6433-6444.

Elmslie KS (1997) Identification of the single channels that underlie the $\mathrm{N}$-type and L-type calcium currents in bullfrog sympathetic neurons. J Neurosci 17:2658-2668.
Hardingham GE, Cruzalegui FH, Chawla S, Bading H (1998) Mechanisms controlling gene expression by nuclear calcium signals. Cell Calcium 23:131-134.

Hell JW, Westenbroek RE, Warner C, Ahlijanian MK, Prystay W, Gilbert MM, Snutch TP, Catterall WA (1993) Identification and differential subcellular localization of the neuronal class $\mathrm{C}$ and class D L-type calcium channel alpha 1 subunits. J Cell Biol 123:949-962.

Hess P, Lansman JB, Tsien RW (1984) Different modes of Ca channel gating behaviour favoured by dihydropyridine $\mathrm{Ca}$ agonists and antagonists. $\mathrm{Na}-$ ture 311:538-544.

Holz IV GG, Dunlap K, Kream RM (1988) Characterization of the electrically evoked release of substance P from dorsal root ganglion neurons: methods and dihydropyridine sensitivity. J Neurosci 8:463-471.

Hoogland TM, Saggau P (2004) Facilitation of L-type $\mathrm{Ca}^{2+}$ channels in dendritic spines by activation of $\beta 2$ adrenergic receptors. J Neurosci 24:8416-8427.

Koschak A, Reimer D, Huber I, Grabner M, Glossmann H, Engel J, Striessnig J (2001) Alpha 1D (Cav1.3) subunits can form L-type Ca2+ channels activating at negative voltages. J Biol Chem 276:22100-22106.

Koschak A, Reimer D, Walter D, Hoda JC, Heinzle T, Grabner M, Striessnig J (2003) Cav1.4 $\alpha 1$ subunits can form slowly inactivating dihydropyridinesensitive L-type $\mathrm{Ca}^{2+}$ channels lacking $\mathrm{Ca}^{2+}$-dependent inactivation. J Neurosci 23:6041-6049.

Lei S, Pelkey KA, Topolnik L, Congar P, Lacaille JC, McBain CJ (2003) Depolarization-induced long-term depression at hippocampal mossy fiber-CA3 pyramidal neuron synapses. J Neurosci 23:9786-9795.

Lipscombe D, Pan QJ, Gray AC (2002) Functional diversity in neuronal voltage-gated calcium channels by alternative splicing of Cav alpha1. Mol Neurobiol 26:21-44.

Lipscombe D, Helton TD, Xu W (2004) L-type Calcium Channels: The Low Down. J Neurophysiol 92:2633-2641.

Liu Z, Ren J, Murphy TH (2003) Decoding of synaptic voltage waveforms by specific classes of recombinant high-threshold $\mathrm{Ca}(2+)$ channels. J Physiol (Lond) 553:473-488.

Ludwig A, Flockerzi V, Hofmann F (1997) Regional expression and cellular localization of the $\alpha 1$ and $\beta$ subunit of high voltage-activated calcium channels in rat brain. J Neurosci 17:1339-1349.

Magee JC, Johnston D (1997) A synaptically controlled, associative signal for Hebbian plasticity in hippocampal neurons. Science 275:209-213.

McCobb DP, Beam KG (1991) Action potential waveform voltage-clamp commands reveal striking differences in calcium entry via low and high voltage-activated calcium channels. Neuron 7:119-127.

Mermelstein PG, Bito H, Deisseroth K, Tsien RW (2000) Critical dependence of cAMP response element-binding protein phosphorylation on L-type calcium channels supports a selective response to EPSPs in preference to action potentials. J Neurosci 20:266-273.

Michna M, Knirsch M, Hoda JC, Muenkner S, Langer P, Platzer J, Striessnig J, Engel J (2003) Cav1.3 (alpha1D) Ca2 + currents in neonatal outer hair cells of mice. J Physiol (Lond) 553:747-758.

Murphy TH, Worley PF, Baraban JM (1991) L-type voltage-sensitive calcium channels mediate synaptic activation of immediate early genes. Neuron 7:625-635.

Perez-Reyes E, Cribbs LL, Daud A, Lacerda AE, Barclay J, Williamson MP, Fox M, Rees M, Lee JH (1998) Molecular characterization of a neuronal low-voltage-activated T-type calcium channel. Nature 391:896-900.

Scroggs RS, Fox AP (1992) Multiple $\mathrm{Ca}^{2+}$ currents elicited by action potential waveforms in acutely isolated adult rat dorsal root ganglion neurons. J Neurosci 12:1789-1801.

Simon M, Perrier JF, Hounsgaard J (2003) Subcellular distribution of L-type Ca2 + channels responsible for plateau potentials in motoneurons from the lumbar spinal cord of the turtle. Eur J Neurosci 18:258-266.

Thaler C, Gray AC, Lipscombe D (2004) Cumulative inactivation of N-type CaV2.2 calcium channels modified by alternative splicing. Proc Natl Acad Sci USA 101:5675-5679.

Weisskopf MG, Bauer EP, LeDoux JE (1999) L-type voltage-gated calcium channels mediate NMDA-independent associative long-term potentiation at thalamic input synapses to the amygdala. J Neurosci 19:10512-10519.

Xu W, Lipscombe D (2001) Neuronal $\mathrm{Ca}_{\mathrm{V}} 1.3_{\alpha 1}$ L-type channels activate at relatively hyperpolarized membrane potentials and are incompletely inhibited by dihydropyridines. J Neurosci 21:5944-5951.

Yasuda R, Sabatini BL, Svoboda K (2003) Plasticity of calcium channels in dendritic spines. Nat Neurosci 6:948-955. 